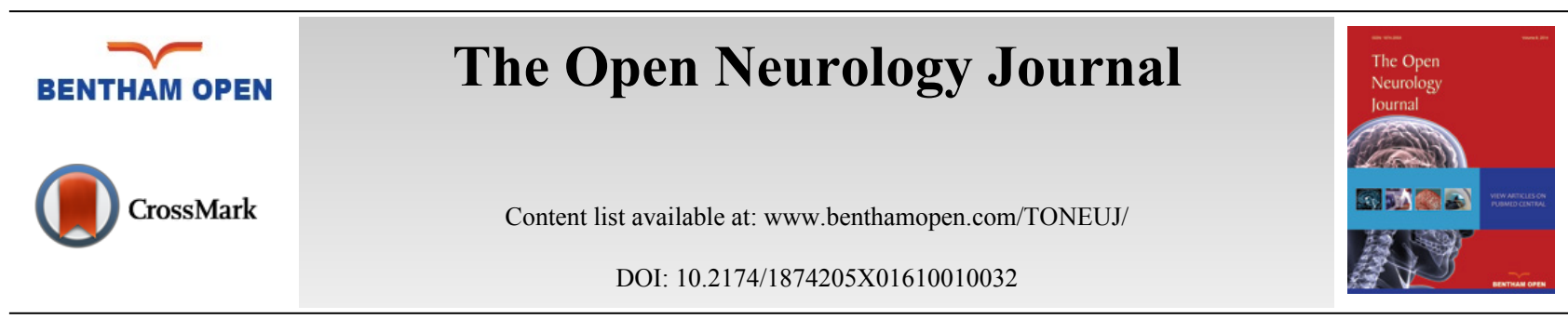

\title{
RESEARCH ARTICLE \\ Nutritional Alterations Associated with Neurological and Neurosurgical Diseases
}

\author{
Yannis Dionyssiotis ${ }^{1, *}$, Aris Papachristos ${ }^{2}$, Konstantina Petropoulou ${ }^{3}$, Jannis Papathanasiou ${ }^{4}$ and \\ Panayiotis Papagelopoulos ${ }^{5}$

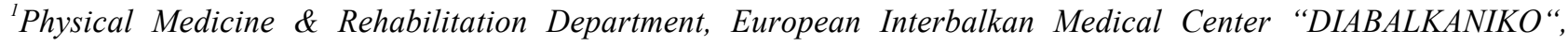 \\ Thessaloniki, Greece \\ ${ }^{2}$ Rehabilitation Center "KENTAVROS", Volos, Thessaly, Greece \\ ${ }^{3} 2^{\text {nd }}$ Physical Medicine \& Rehabilitation Department, National Rehabilitation Center "EKA-KAT", Ilion, Athens, \\ Greece \\ ${ }^{4}$ Section of Kinesiotherapy \& Physiotherapy Department of Preventive Medicine, Medical University of Sofia, Sofia, \\ Bulgaria \\ ${ }^{5} 1^{\text {st }}$ Department of Orthopaedics, General University Hospital "ATTIKON”, Athens, Greece
}

\begin{abstract}
Neurological and neurosurgical diseases lead to complications producing malnutrition increasing pathology and mortality. In order to avoid complications because of malnutrition or overcome deficiencies in nutrients supplements are often used for these subjects. The physiopathological mechanisms of malnutrition, methods of nutritional assessment and the supplemental support are reviewed in this paper based on the assumption that patients need to receive adequate nutrition to promote optimal recovery, placing nutrition as a first line treatment and not an afterthought in the rehabilitation.
\end{abstract}

Keywords: Disabled, Malnutrition, Neurological, Neurosurgical, Rehabilitation.

\section{INTRODUCTION}

Nutritional problems are an important issue of rehabilitation in all disabled subjects especially in neurological and neurosurgical patients. Common diagnoses of patients admitted to a neuro intensive care unit (NICU) include traumatic brain injury, stroke, brain tumor, spinal cord injury, degenerative disease (multiple sclerosis, amyotrophic lateral sclerosis, Alzheimer's, Parkinson's) or a mobility disorder (myasthenia gravis, Guillain-Barre syndrome) [1, 2].

Neurological and neurosurgical diseases have differences according to lesion, injury, life expectancy, residual mobility-functionality and drug treatment. On the other side diseases with different physiopathology, location, evolution, etc. could be presented with a similar clinical picture [3]. In children with cerebral palsy (CP) locomotion is limited because of increased stretch reflexes, muscle tone and weakness of involved musculature. Hypertonia (high muscle tone, spasticity) is limiting muscle movement in CP and reduces caloric needs while in other disabled conditions hypotonia (low muscle tone, floppiness) results in a lower resistance to muscle movement and fewer calories burned during movement. Lack of movement results in muscle atrophy and a lower lean body mass, which in turn reduces the number of calories burned even at rest [4]. Immobilization periods because of infections or operations become another barrier in the daily activities of these populations [3]. In spinal cord injured subjects mainly central or abdominal obesity was found leading to metabolic, cardiovascular issues etc. However, there is conflicting evidence about the

\footnotetext{
* Address correspondence to this author at the 1 Rimini Street, 12462, Chaidari, Greece; Tel: 00306946469759; E-mail: yannis_dionyssiotis@hotmail.com
} 
contribution of visceral and subcutaneous adipose tissue to different metabolic disorders after SCI. Reduced physical activity in MS because of functional disability need to be accompanied by a reduction in energy intake otherwise body fat will increase. Mobility is also limited by factors such as depression and fatigue. Nevertheless, MS would likely have a much greater effect on physical activity than on energy intake. No significant relation between the level of physical activity, and the level of disability in individuals with MS was found [5]. In clinical practice and according to these patients no single parameter can continually assess the nutritional status or provide the effect of diet in preventing and treating complications [6]. For an initial assessment of nutritional status serial measurements to assess trends over time and then monitor the response to a dietary intervention may be useful.

Dysphagia is an important complication in many disabled conditions, found in up to $67 \%$ of patients with a stroke [7]. During hospitalization adequate intake of nutrients is intercepted by many factors, and may be caused by anorexia, early satiety, dysgeusia, smelling problems, immobility, depression, and swallowing disorder i.e. dysphagia or silent aspiration, (caused by a cervical spine stabilization vest like Halo type or other restrictive devices, i.e. a tracheotomy tube, and injuries or nerve palsies and requires parenteral or enteral support, as soon as possible to prevent pressure ulcers).

This paper presents methods of nutritional assessment and describes the physiopathological mechanisms of malnutrition and the nutritional support which can be used in neurological and neurosurgical subjects.

\section{A COMPREHENSIVE NUTRITIONAL ASSESSMENT OF A NEURO-DISABLED SUBJECT}

\section{Equations for Calculation of Metabolic Needs}

A group of equations are presented in the current paper. Among these are Mifflin-St Jeor equation [8], the HarrisBenedict equation [9], the American College of Chest Physicians (ACCP) recommendation based on $\mathrm{kcal} / \mathrm{kg}$ body weight [10], the Faisy equation [11], the Ireton-Jones equations [12, 13] and the Penn State equations [14, 15]. The Harris-Benedict is calculated by sex with the following formula: Men: Resting Metabolic Rate $(\mathrm{RMR})(\mathrm{kcal} / \mathrm{d})=67+$ Body Weight x 13.75+ Height x 5 - Age x 6.8 [15]; Women: RMR (kcal/d) = $655+$ Body Weight x 9.6 + Height x 1.85 - Age x 4.7 [16]. The ACCP equation was designed for critically ill patients, so no multiplier was applied. The ACCP equation is often used with modified body weights, so the equation is used with ideal body weight and actual body weight in the underweight patients and actual, ideal, and calculated metabolically active body weight (MAW) in the morbidly obese patients [10]. The Hamwi rule of thumb is used for ideal body weight calculation and MAW is calculated as $25 \%$ of excess weight (actual weight - ideal weight) added to the ideal body weight [17]. The Ireton-Jones equations include one specifically for obese patients and one for general critical care populations: Obesity: RMR $(\mathrm{kcal} / \mathrm{d})=$ Wt x $9+$ Gender x $606-$ Age x $12+1844$ [18]; non-obese: RMR (kcal/d) = Wt x 5 - Age x $10+$ Gender x $281+$ Trauma $\times 292+1925$ (for gender: male=1, female=0) [19].

Two versions of the Penn State equation have been validated [12, 13]. The standard equation was used in all underweight patients and all obese patients younger than 60 years. However, the standard equation has been found previously to be inaccurate in patients 60 years or older with a body mass index $30 \mathrm{~kg} / \mathrm{m} 2$ or higher [12]. Thus, a modified equation was developed and validated [13].

Standard equation: RMR (kcal/d) = Mifflin x $0.96+$ Tmax x $167+$ Ve x $31-6212$ [20], Modified equation: RMR $(\mathrm{kcal} / \mathrm{d})=$ Mifflin x 0.71+ Tmax x $85+$ Ve x $64-3085$ [21], where Mifflin is the Mifflin-St Jeor equation calculated from actual body weight, height, age, and sex [8]; Tmax is maximum body temperature in degrees centigrade; and Ve is expired minute ventilation in $\mathrm{L} / \mathrm{min}$ recorded from the mechanical ventilator at the time of the indirect calorimetry measurement. The Faisy equation is structured similarly to the Penn State equation, but it uses body weight and height instead of the Mifflin to account for body size and composition, as well as current body temperature instead of maximum body temperature [11]: RMR (kcal/d): Wt x $8+$ Ht x $14+$ Ve x $32+$ Temp x $94-4834$ [22].

\section{Anthropometrics}

Anthropometric data such as body mass index (BMI), ideal body weight (IBW), triceps skin fold thickness and the middle arm circumference which are common tools for assessment of nutrition may not be valid for disabled subjects [3]. In chronic spinal cord injury (SCI) population BMI values were not significant vs. controls [23]. However, others demonstrated the usefulness of BMI as an indicator of obesity [24] which puts BMI cut off values into the following question: do the cut-points for underweight, normal, overweight, and obese used in able-bodied populations apply to disabled subjects? [25 - 27]. Nevertheless, BMI in patients with multiple sclerosis (MS) was found significantly lower 
compared to age comparable controls [28]. Among children with cerebral palsy found that the triceps, midthigh, and calf skinfold thicknesses of the affected side were greater than those of the no affected side [29]. In disabled children techniques for measuring skinfolds are well established and standardised and equations are available for calculation of body fat from skin fold thickness although invalidated in this population; consequently, use of skinfold thickness should be used with discretion in the assessment of children with CP, who tend to have muscle wasting [30 - 33].

\section{Biochemical Measurements}

Specific proteins and other biochemical markers are indicators used for assessing nutritional status. Most important are albumin, transferrin, pre-albumin and physical measurements of nitrogen and creatinine/height index. These are extensively analyzed in a previous publication. Pre-albumin looks the most valued of them [34].

\section{Dysphagia and Other Problems During Eating}

Assistance during meals may be needed if subjects are not in a position to feed by themselves, but using adaptive equipment they can become more independent [3]. Neurological diseases can cause sensory problems in the mouth or in the throat leading to dysphagia. Some neurological disorders can cause the weakening of certain muscles or muscle groups, making food stuck in the throat while other lead to reduced laryngeal closure, so that (silent) aspiration can result. The coordination of the swallowing process can be affected by certain neurological disorders that adversely affect the motor sequence of swallowing.

Sensory problems are frequent in stroke patients, but they often occur with other neurological disorders [35]. Due to decreased pharyngeal sensitivity the coordination between swallowing and laryngeal closure is disrupted. The bolus passes into the throat, before the pharyngeal phase of swallowing is triggered. In general, these patients aspirate thin fluids [36]. Other neurological disabilities can cause motor problems (i.e. at the level of the pharyngeal and laryngeal muscles). Due to the general weakness chewing can be difficult, and the pharyngeal muscles may no longer be able to carry the bolus into the esophagus. In some patients, the lip closure due to facial paralysis is insufficient, or the bolus cannot be collected at the center of the tongue when the tongue muscles are paralyzed. The results are food residuals in the mouth [35, 37]. Swallowing requires motor planning and coordination. It is known that, some neurological conditions, such as stroke and dementia, affecting the motor sequence of swallowing. In these cases, apraxia of swallowing can occur: A patient transport food into the mouth, but seems to have forgotten what to do with it on. Problems in the coordination of swallowing can lead to a condition in which certain structures (pharyngeal constrictor muscle or upper esophageal sphincter) respond well to the motor swallowing, but not in the normal sequence [35, 38].

Screening for swallowing difficulty is a key part of the clinical assessment of an acute patient. Swallow safety must be evaluated as soon as possible after admission by trained personnel (i.e. physician, speech therapist). Usually, small volumes of water are administered and a judgment is made about whether the patient coughs, has a change in voice quality, respiratory patterns, pooling of fluid within the oral cavity or leakage from the mouth. Clinical observation and detailed swallow assessment (including behaviour, function and cognition as it relates to swallowing and assessment with a broader range of food and fluids of varying texture and consistency) [39].

Videofluoroscopy (VF) is the 'gold' standard assessment for the detection of aspiration and its underlying pathophysiology. It is the only technique that can evaluate the efficacy of therapeutic interventions such as postural techniques and dietary modifications. However, it has some limitations that patients need to be able to sit up and follow detailed instructions and that specially-trained staff are required [39]. The sophisticated technique of fibreoptic endoscopic evaluation of swallowing (FEES) can be used for aspiration diagnosis. It involves the trans-nasal insertion of a fibreoptic nasendoscope to the level of the oropharynx/hypopharynx to evaluate laryngopharyngeal physiology, management of secretions and the ability to swallow food and fluids [40]. A number of studies have reported that FEES is a valid tool for detecting aspiration, penetration and pharyngeal residue when compared with videofluoroscopy [41 45]. FEES is not associated with radiation exposure, can be performed at the bedside, repeated whenever necessary, however, it requires the patient to be compliant and able to follow instructions [39].

Neurodisabled subjects require an initial screening during admission to detect early malnourished patients who are at increased risk of developing malnutrition. Recently, the Dutch Health Care Inspectorate (HCI) has defined under nutrition as a main care problem in rehabilitation centres. Till now screening tools to detect a patient's nutritional status have been developed in many healthcare settings, but not in the rehabilitation setting. The Short Nutritional Assessment Questionnaire (SNAQ) is the recommended screening tool according to HCI for nutrition screening in rehabilitation centres [46 - 48] (Fig. 1). 


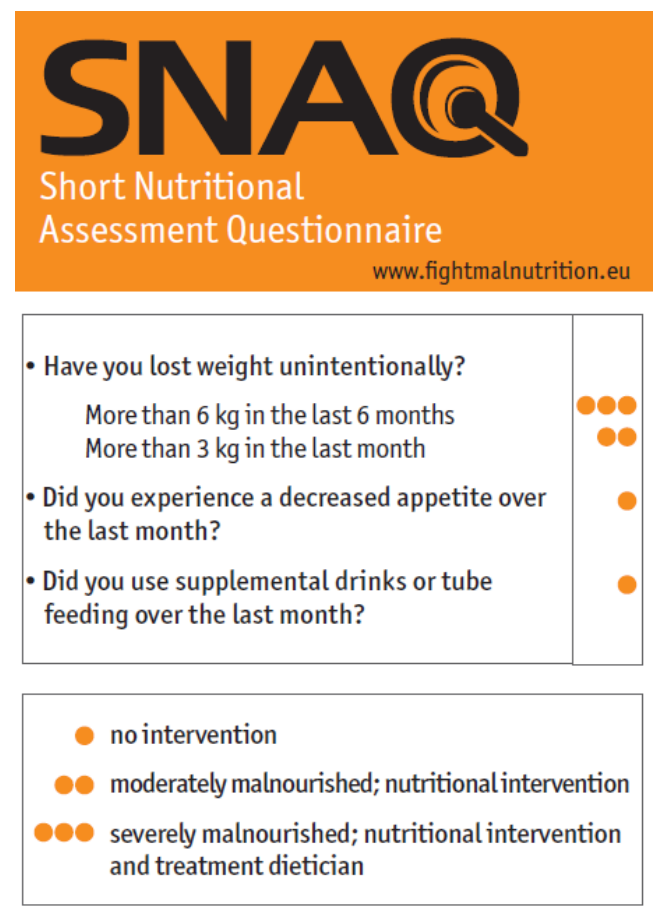

Fig. (1). The Short Nutritional Assessment Questionnaire (SNAQ). To get an insight into hospitalized patients nutritional status an easy-to-use screening tool is developed. Published with permission from: http://www.fightmalnutrition.eu/fight-malnutrition/ screening-tools/

\section{Monitoring}

Nutrition issues are responsibility of rehabilitation's healthcare professionals with relevant skills and training. Indications, route, risks, benefits and goals of nutrition support at regular intervals, time between reviews depending on the patient, care setting and duration of nutrition support all require extensive and specialized training. More information is included in NICE Clinical Guideline 32 Feb.2006 Nutrition Support in Adults: Oral Nutrition Support, Enteral Tube Feeding and Parenteral Nutrition [49] and the whole guideline can be downloaded from: http://www.nice.org.uk/nicemedia/live/10978/29979/29979.pdf)

\section{PHYSIOPATHOLOGY OF MALNUTRITION}

Pathophysiological mechanisms of malnutrition in neurological and neurosurgical disabilities are multifactorial [50 - 57]. The metabolic changes in acute phase of the injury are presented in Fig. (2). Catabolism is further increased by coexistence of injuries from other systems, such as multiple organ trauma, soft tissue injuries, brain injury, spinal cord injury, maxillofacial injuries, fractures, etc.

During aging with a disability, other complications are added in the physiopathological context of "malnourished disabled subjects": pneumonia, aspiration, skin ulcers and neurogenic bowel are frequent complications of disabled subjects. Increased risk for cardiovascular disease and cardiopulmonary disease because of extensive fat intake and limiting activities has to be taken in mind. Vitamin D deficiency due to a combination of low dietary vitamin D intake and avoiding sun exposure because of depression or sensitivity in drugs i.e. dantrolene [58]. The low intake of vitamin D, which is supplied by food either in vitamin D2 (ergocalciferol, activated ergosterol), found in yeast, or vitamin D3 (cholecalciferol), found in fish, can be bypassed through supplements [59]. Excessive excretion of potassium and abnormal hyponatremia; hypercalcemia, due to immobilization, particularly in young men and hypercalciuria exceed the normal range in 4 weeks, with higher values at 16 weeks, which can persist for a long time. Hypercalcemia occurs with anorexia, abdominal cramps, nausea, vomiting, constipation, polydipsia, polyuria, dehydration and did not respond to diets which restrict the intake of calcium and need to be treated with medication, hydration, and mobilization [60]. 


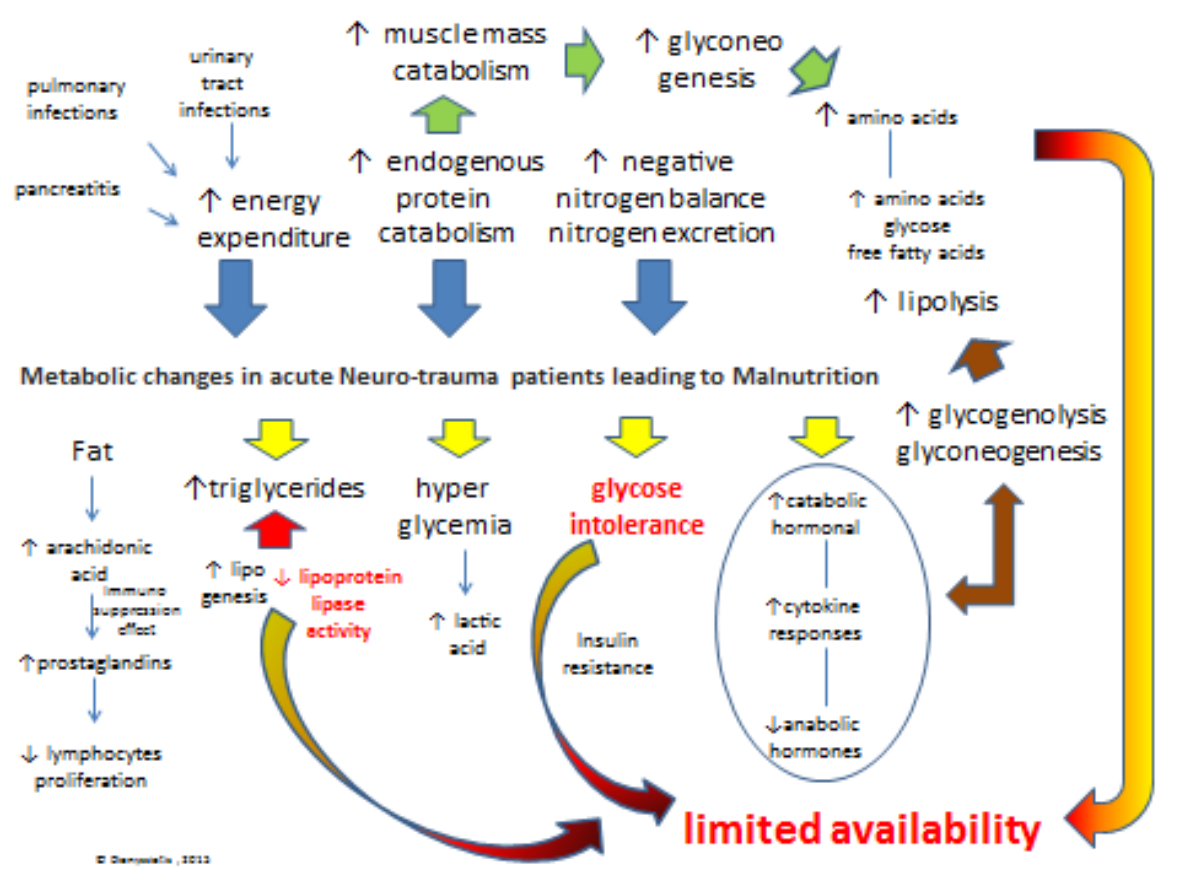

Fig. (2). Metabolic changes in acute Neurotrauma patients leading to Malnutrition: There is a dramatic increase (see blue arrows) in energy expenditure, endogenous protein catabolism and nitrogen excretion after lesion-injury. Primary metabolic changes include an hormonal cataract (see yellow arrows) with elevated catabolic hormonal and cytokine responses in blood serum (i.e. cortisol, catecholamines, and glucagon) and peripheral-tissue resistance to endogenous anabolic hormones (i.e. insulin and insulin-like growth factor 1) and increased blood and tissue levels of proinflammatory cytokines (i.e. interleukin-1, interleukin-6, interleukin-8, and tumor necrosis factor $\alpha$ ), respectively. Glucose intolerance may be caused by hyper metabolic-catabolic stress response, administration of steroids, the parenteral/enteral nutrition, and atrophy as a consequence of aponeurosis which results in gluconeogenesis. Hyperglycemia follows head injury or spinal cord increase the production of lactic acid, which may have the reverse effect on neurological recovery from injury. Unfortunately, increases in glycogenolysis and gluconeogenesis, is enhancing lipolysis, which provides endogenous glucose, amino acids, and free fatty acids (see brown arrows) that are required for cellular and organ function and wound healing but are insufficient to meet metabolic needs due to limited availability for use by peripheral tissues because of insulin resistance and inhibition of lipoprotein lipase (see limited availability in red). Another serious metabolic issue is negative nitrogen balance, due to excessive secretion of nitrogen because of protein use (mainly due to pulmonary infections or urinary tract infractions, and pancreatitis).

\section{THE NUTRITIONAL SUPPORT}

Neurological or neurosurgical subjects are frequently either in coma in the early phase of injury or have impaired swallowing ability. For this reason parenteral nutrition (PN) or enteral tube feeding is needed [61, 62]. A critically ill intensive care unit (ICU) patient may be an appropriate candidate for PN under certain circumstances: (1) wellnourished prior to admission, but after 7 days of hospitalization, EN has not been feasible or target goal calories have not been met consistently by EN alone, (2) on admission, the patient is malnourished and EN is not feasible. A major surgical procedure is planned, the preoperative assessment indicates that EN is not feasible through the perioperative period, and the patient is malnourished. In ICU patients the use of PN has been associated with increased mortality rates and several other complications including gut mucosal atrophy, overfeeding, hyperglycaemia and an increased risk of infectious complications [63, 64].

Enteral nutrition (EN) is recommended for patients who are tubed, not able to swallow or to receive adequate diet orally with adequate bowel function and may be categorized in continuous enteral nutrition which is a credible route of nutrition intervention, requiring pump maintenance (Fig. 3) and Table $\mathbf{1}$ which is the initial phase of enteral feeding or single (bolus) injection effected by gravity or syringe, typically applied in rehabilitation patients who are stable [3]. 


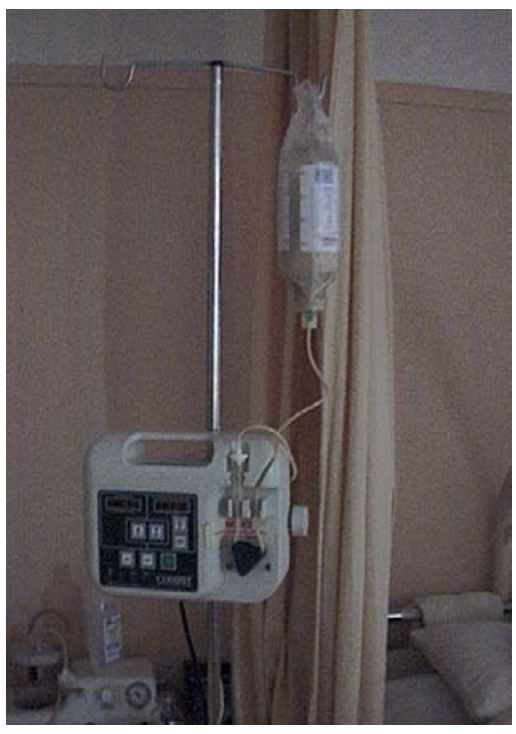

Fig. (3). The enteral feeding pump type COMPAT. The system is a relatively simple, lightweight, easy to use for managing all types of enteral feeding. Have an audible and visual alarm that alerts you when each of the following conditions: empty container feeding, low battery, change the dose, or the existence of $\mathrm{j}$ free flow out of the system (waste). The memory of the pump retains infusion rate, volume delivered, dose limit even after turning it off. It is designed to provide precision dosing. Figure adapted from Dionyssiotis $\mathrm{Y}^{3}$ with permission

Table 1. Advantages of early nutrition EN in neurological and neurosurgical patients.

\begin{tabular}{|c|c|}
\hline \multicolumn{2}{|c|}{ Early Enteral Nutrition (EN) } \\
\hline Advantages & Disadvantages \\
\hline Reduces catabolism & High gastric residuals \\
\hline Reduces complications & Bacterial colonization of the stomach \\
\hline Reduces length of stay & Increased risk of aspiration pneumonia \\
\hline
\end{tabular}

On the other side during the acute rehabilitation period oral nutritional therapy is modified compared to normal life. Nutrition via assisted feeding with the help from therapists and the use of dietary supplements is often difficult, timeconsuming and demanding (due to multimorbidity and slow responses) $[65,66]$. The provision of a nutritional supplement is more an adjunctive in order to optimize the nutritional status rather than an alternative solution for increasing poor oral intake. Independency during eating is crucial here and the food itself is not always what causes patient's problems, which could be associated with his functional status. Upper limbs functionality is important: In case patient has a disability of the upper limb, regardless of the diet, the important issue is to achieve independence during feeding. Hearing ability also affects the recruitment of patients, including those who may have an appetite for feeding. Difficulties in chewing food can occur in certain situations, including malposessed dentures, missing teeth, poor oral hygiene, and oral infections [3]. Another interesting finding already reported in earlier meta-analysis: there is no increased mortality risk with parenteral nutrition! [67] A meta-analysis of early EN in "critically ill" surgical patients supported the view that it reduces the incidence of infection but evidence that real outcome is influenced is lacking [68]. Even though the evidence favours enteral nutrition, due to its lower risk of complications and low cost, problems such as alteration of consciousness level and gastric motility abnormalities can delay the beginning of enteral tube feeding, leading to the more frequent use of parenteral nutrition in the first week following the neurological injury [69].

Placement of a percutaneous endoscopic gastrostomy (PEG) tube should be considered for patients who continue to require enteral feeding beyond 4 weeks [70, 71]. Advantages of a PEG compared to a nasogastric feeding tube are twofold: it does not interfere with the swallowing mechanism, especially when oral feeding is initiated during neurological recovery and it can be invisible underneath the clothes. However, the risk of aspiration, is not eliminated with PEG placement [72].

Deficiencies in zinc and vitamin $\mathrm{C}$ have been associated with poor wound healing. Vitamin $\mathrm{C}$ deficiencies result in impaired healing because of role of vitamin $\mathrm{C}$ in collagen synthesis and fibroblast proliferation, decreased angiogenesis, and increased capillary fragility [73]. Among several micronutrients Zinc is known to be involved in structural integrity of collagen, and a zinc deficiency causes a significant impairment in wound healing. Zinc is often prescribed to improve 
stress ulcers [73, 74]. Moreover, given that the subclinical deficiencies are difficult to show up, the minimum recommended dietary intake is proposed to $60 \mathrm{mg}[75]$.

\section{REFERENCES}

[1] Roubenoff RA, Borel CO, Hanley DF. Hypermetabolism and hypercatabolism in Guillain-Barré syndrome. JPEN J Parenter Enteral Nutr 1992; 16(5): 464-72. [http://dx.doi.org/10.1177/0148607192016005464] [PMID: 1433782]

[2] Ghanbari C. Protocols for nutrition support of neuro intensive care unit patients: a guide for residents. Inter J Emerg Inten Care Med 2002; 6: 106-9.

[3] Dionyssiotis Y. Dual Energy X-Ray Absorptiometry. Rijeka, Croatia: InTech 2012; pp. 75-94.

[4] Yin L, McLennan M, Bellou TF. Overweight in children with intellectual disabilities: No Simple Matter. ICAN: Infant, Child, \&. Adolescent Nutrition 2013; 5: 92-6.

[5] Dionyssiotis Y. Body composition in multiple sclerosis. Hippokratia 2013; 17(1): 7-11. [PMID: 23935336]

[6] Buzby GP, Mullen JL. Nutritional Assessment. Oxford: Blackwell Scientific 1984; pp. $27-82$.

[7] Young EC, Durant-Jones L. Developing a dysphagia program in an acute care hospital: a needs assessment. Dysphagia 1990; 5(3): 159-65. [http://dx.doi.org/10.1007/BF02412640] [PMID: 2123428]

[8] Mifflin MD, St Jeor ST, Hill LA, Scott BJ, Daugherty SA, Koh YO. A new predictive equation for resting energy expenditure in healthy individuals. Am J Clin Nutr 1990; 51(2): 241-7. [PMID: 2305711]

[9] Harris JA, Benedict FG. A biometric study of human basal metabolism. Proc Natl Acad Sci USA 1918; 4(12): $370-3$. [http://dx.doi.org/10.1073/pnas.4.12.370] [PMID: 16576330]

[10] Cerra FB, Benitez MR, Blackburn GL, et al. Applied nutrition in ICU patients. A consensus statement of the American College of Chest Physicians. Chest 1997; 111(3): 769-78. [http://dx.doi.org/10.1378/chest.111.3.769] [PMID: 9118718]

[11] Faisy C, Guerot E, Diehl JL, Labrousse J, Fagon JY. Assessment of resting energy expenditure in mechanically ventilated patients. Am J Clin Nutr 2003; 78(2): 241-9.

[PMID: 12885704]

[12] Ireton-Jones CS, Turner WW Jr, Liepa GU, Baxter CR. Equations for the estimation of energy expenditures in patients with burns with special reference to ventilatory status. J Burn Care Rehabil 1992; 13(3): 330-3. [http://dx.doi.org/10.1097/00004630-199205000-00005] [PMID: 1618877]

[13] Ireton-Jones CS, Turner WW Jr. Actual or ideal body weight: which should be used to predict energy expenditure? J Am Diet Assoc 1991; 91(2): 193-5.

[PMID: 1899436]

[14] Frankenfield DC, Coleman A, Alam S, Cooney RN. Analysis of estimation methods for resting metabolic rate in critically ill adults. JPEN J Parenter Enteral Nutr 2009; 33(1): 27-36. [http://dx.doi.org/10.1177/0148607108322399] [PMID: 19011147]

[15] Frankenfield D. Validation of an equation for resting metabolic rate in older obese, critically ill patients. JPEN J Parenter Enteral Nutr 2011; 35(2): 264-9. [http://dx.doi.org/10.1177/0148607110377903] [PMID: 21378256]

[16] Frankenfield DC, Ashcraft CM, Galvan DA. Longitudinal prediction of metabolic rate in critically ill patients. JPEN J Parenter Enteral Nutr 2012; 36(6): 700-12.

[http://dx.doi.org/10.1177/0148607112446702] [PMID: 22577122]

[17] Hamwi GJ. Diabetes Mellitus: Diagnosis and Treatment. New York: American Diabetes Association 1964; vol. 1: pp. 73-8.

[18] Frankenfield D, Hise M, Malone A, Russell M, Gradwell E, Compher C. Evidence Analysis Working Group. Prediction of resting metabolic rate in critically ill adult patients: results of a systematic review of the evidence. J Am Diet Assoc 2007; 107(9): 1552-61. [http://dx.doi.org/10.1016/j.jada.2007.06.010] [PMID: 17761232]

[19] Campbell CG, Zander E, Thorland W. Predicted vs. measured energy expenditure in critically ill, underweight patients. Nutr Clin Pract 2005; 20(2): 276-80.

[http://dx.doi.org/10.1177/0115426505020002276] [PMID: 16207663]

[20] Alberda C, Snowden L, McCargar L, Gramlich L. Energy requirements in critically ill patients: how close are our estimates? Nutr Clin Pract 2002; 17(1): 38-42. [http://dx.doi.org/10.1177/011542650201700138] [PMID: 16214965]

[21] Ahmad A, Duerksen DR, Munroe S, Bistrian BR. An evaluation of resting energy expenditure in hospitalized, severely underweight patients. Nutrition 1999; 15(5): 384-8. [http://dx.doi.org/10.1016/S0899-9007(99)00068-4] [PMID: 10355852] 
[22] Amato P, Keating KP, Quercia RA, Karbonic J. Formulaic methods of estimating calorie requirements in mechanically ventilated obese patients: a reappraisal. Nutr Clin Pract 1995; 10(6): 229-32. [http://dx.doi.org/10.1177/0115426595010006229] [PMID: 8700053]

[23] Dionyssiotis Y, Petropoulou K, Rapidi CA, et al. Body composition in paraplegic men. J Clin Densitom 2008; 11(3): 437-43. [http://dx.doi.org/10.1016/j.jocd.2008.04.006] [PMID: 18534884]

[24] Gupta N, White KT, Sandford PR. Body mass index in spinal cord injury - a retrospective study. Spinal Cord 2006; 44(2): 92-4. [http://dx.doi.org/10.1038/sj.sc.3101790] [PMID: 16030513]

[25] Jones LM, Legge M, Goulding A. Healthy body mass index values often underestimate body fat in men with spinal cord injury. Arch Phys Med Rehabil 2003; 84(7): 1068-71. [http://dx.doi.org/10.1016/S0003-9993(03)00045-5] [PMID: 12881836]

[26] Buchholz AC, Bugaresti JM. A review of body mass index and waist circumference as markers of obesity and coronary heart disease risk in persons with chronic spinal cord injury. Spinal Cord 2005; 43(9): 513-8. [http://dx.doi.org/10.1038/sj.sc.3101744] [PMID: 15824757]

[27] Laughton GE, Buchholz AC, Martin Ginis KA, Goy RE. SHAPE SCI Research Group. Lowering body mass index cutoffs better identifies obese persons with spinal cord injury. Spinal Cord 2009; 47(10): 757-62. [http://dx.doi.org/10.1038/sc.2009.33] [PMID: 19350042]

[28] Formica CA, Cosman F, Nieves J, Herbert J, Lindsay R. Reduced bone mass and fat-free mass in women with multiple sclerosis: effects of ambulatory status and glucocorticoid Use. Calcif Tissue Int 1997; 61(2): 129-33. [http://dx.doi.org/10.1007/s002239900309] [PMID: 9236259]

[29] Stevenson RD, Roberts CD, Vogtle L. The effects of non-nutritional factors on growth in cerebral palsy. Dev Med Child Neurol 1995; 37(2): 124-30. [http://dx.doi.org/10.1111/j.1469-8749.1995.tb11981.x] [PMID: 7851668]

[30] Lohman TG, Roche AF, Martorell R. Anthropometric standardization reference manual. Champaign: Human Kinetics Books 1988.

[31] Slaughter MH, Lohman TG, Boileau RA, et al. Skinfold equations for estimation of body fatness in children and youth. Hum Biol 1988; 60(5): 709-23. [PMID: 3224965]

[32] Frisancho AR. New norms of upper limb fat and muscle areas for assessment of nutritional status. Am J Clin Nutr 1981; $34(11)$ : 2540-5. [PMID: 6975564]

[33] Kuperminc MN, Stevenson RD. Growth and nutrition disorders in children with cerebral palsy. Dev Disabil Res Rev 2008; 14(2): 137-46. [http://dx.doi.org/10.1002/ddrr.14] [PMID: 18646022]

[34] Dionyssiotis Y. Malnutrition in spinal cord injury: more than nutritional deficiency. J Clin Med Res 2012; 4(4): 227-36. [PMID: 22870169]

[35] Rofes L, Arreola V, Almirall J, et al. Diagnosis and management of oropharyngeal Dysphagia and its nutritional and respiratory complications in the elderly. Gastroenterol Res Pract $20112011 ; 818-979$. [http://dx.doi.org/10.1155/2011/818979]

[36] Matsuo K, Palmer JB. Anatomy and physiology of feeding and swallowing: normal and abnormal. Phys Med Rehabil Clin N Am 2008; 19(4): 691-707, vii. [http://dx.doi.org/10.1016/j.pmr.2008.06.001] [PMID: 18940636]

[37] Logemann J. Evaluation and treatment of swallowing disorders. $2^{\text {nd }}$ ed. Austin, TX: Pro-Ed 2006.

[38] Easterling CS, Robbins E. Dementia and dysphagia. Geriatr Nurs 2008; 29(4): 275-85. [http://dx.doi.org/10.1016/j.gerinurse.2007.10.015] [PMID: 18694703]

[39] National Collaborating Centre for Chronic Conditions. Stroke: national clinical guideline for diagnosis and initial management of acute stroke and transient ischaemic attack (TIA). London: Royal College of Physicians 2008.

[40] Kelly AM, Hydes K, McLaughlin C, Wallace S. Fibreoptic Endoscopic Evaluation of Swallowing (FEES): The role of speech and language therapy. RCSLT Policy Statement 2007.

[41] Langmore SE, Schatz K, Olson N. Endoscopic and videofluoroscopic evaluations of swallowing and aspiration. Ann Otol Rhinol Laryngol 1991; 100(8): 678-81. [http://dx.doi.org/10.1177/000348949110000815] [PMID: 1872520]

[42] Périé S, Laccourreye L, Flahault A, Hazebroucq V, Chaussade S, St Guily JL. Role of videoendoscopy in assessment of pharyngeal function in oropharyngeal dysphagia: comparison with videofluoroscopy and manometry. Laryngoscope 1998; 108(11 Pt 1): $1712-6$. [http://dx.doi.org/10.1097/00005537-199811000-00022] [PMID: 9818831]

[43] Kelly AM, Leslie P, Beale T, Payten C, Drinnan MJ. Fibreoptic endoscopic evaluation of swallowing and videofluoroscopy: does examination type influence perception of pharyngeal residue severity? Clin Otolaryngol 2006; 31(5): 425-32. [http://dx.doi.org/10.1111/j.1749-4486.2006.01292.x] [PMID: 17014453]

[44] Kelly AM, Drinnan MJ, Leslie P. Assessing penetration and aspiration: how do videofluoroscopy and fiberoptic endoscopic evaluation of swallowing compare? Laryngoscope 2007; 117(10): 1723-7. 
[http://dx.doi.org/10.1097/MLG.0b013e318123ee6a] [PMID: 17906496]

[45] Rao N, Brady SL, Chaudhuri G, Donzelli JJ, Wesling MW. Gold-standard? Analysis of the videofluoroscopic and fiberoptic endoscopic swallow examinations. J Appl Res 2003; 3: 89-96.

[46] Hertroijs D, Wijnen C, Leistra E, Visser M, van der Heijden E, Kruizenga H. Rehabilitation patients: undernourished and obese? J Rehabil Med 2012; 44(8): 696-701. [http://dx.doi.org/10.2340/16501977-0993] [PMID: 22729799]

[47] [Set Performance Indicator rehabilitation centers.] Commissie Prestatie-indicatoren Revalidatie Nederland en Nederlands Vereniging van Revalidatieartsen 2011. (in Dutch)

[48] Kruizenga HM, Seidell JC, de Vet HC, Wierdsma NJ, van Bokhorst-de van der Schueren MA. Development and validation of a hospital screening tool for malnutrition: the short nutritional assessment questionnaire (SNAQ). Clin Nutr 2005; 24(1): 75-82. [http://dx.doi.org/10.1016/j.clnu.2004.07.015] [PMID: 15681104]

[49] National Collaborating Centre for Acute Care (UK). National Collaborating Centre for Acute Care (UK) Nutrition Support for Adults: Oral Nutrition Support, Enteral Tube Feeding and Parenteral Nutrition. London: National Collaborating Centre for Acute Care (UK) 2006.

[50] Kolpek JH, Ott LG, Record KE, et al. Comparison of urinary urea nitrogen excretion and measured energy expenditure in spinal cord injury and nonsteroid-treated severe head trauma patients. JPEN J Parenter Enteral Nutr 1989; 13(3): $277-80$. [http://dx.doi.org/10.1177/0148607189013003277] [PMID: 2761068]

[51] Claus-Walker J, Halstead LS. Metabolic and endocrine changes in spinal cord injury: IV. Compounded neurologic dysfunctions. Arch Phys Med Rehabil 1982; 63(12): 632-8. [PMID: 7149949]

[52] Wilmore DW. Catabolic illness. Strategies for enhancing recovery. N Engl J Med 1991; 325(10): 695-702 [http://dx.doi.org/10.1056/NEJM199109053251005] [PMID: 1908058]

[53] Burnham EL, Moss M, Ziegler TR. Myopathies in critical illness: characterization and nutritional aspects. J Nutr 2005; $135(7)$ : 1818S-23. [PMID: 15987872]

[54] Bongers T, Griffiths RD, McArdle A. Exogenous glutamine: the clinical evidence. Crit Care Med 2007; 35(9)(Suppl.): S545-52. [http://dx.doi.org/10.1097/01.CCM.0000279193.23737.06] [PMID: 17713407]

[55] Cree MG, Wolfe RR. Postburn trauma insulin resistance and fat metabolism. Am J Physiol Endocrinol Metab 2008; 294(1): E1-9. [http://dx.doi.org/10.1152/ajpendo.00562.2007] [PMID: 17957035]

[56] Thibault-Halman G, Casha S, Singer S, Christie S. Acute management of nutritional demands after spinal cord injury. J Neurotrauma 2011; 28(8): 1497-507.

[http://dx.doi.org/10.1089/neu.2009.1155] [PMID: 20373845]

[57] Robertson CS, Grossman RG. Protection against spinal cord ischemia with insulin-induced hypoglycemia. J Neurosurg 1987; 67(5): 739-44. [http://dx.doi.org/10.3171/jns.1987.67.5.0739] [PMID: 3312514]

[58] Bauman WA, Zhong YG, Schwartz E. Vitamin D deficiency in veterans with chronic spinal cord injury. Metabolism 1995; $44(12)$ : 1612-6. [http://dx.doi.org/10.1016/0026-0495(95)90083-7] [PMID: 8786732]

[59] Dionyssiotis Y. Bone loss and fractures in multiple sclerosis: focus on epidemiologic and physiopathological features. Int J Gen Med 2011; 4: $505-9$. [http://dx.doi.org/10.2147/IJGM.S22255] [PMID: 21845056]

[60] Peruzzi WT, Shapiro BA, Meyer PR Jr, Krumlovsky F, Seo BW. Hyponatremia in acute spinal cord injury. Crit Care Med 1994; $22(2)$ : 252-8. [http://dx.doi.org/10.1097/00003246-199402000-00016] [PMID: 8306684]

[61] Endersbe LA. Nutrition support dietetics. Aspen, Maryland: Silver 1989; pp. 107-18.

[62] Jacksic T, Blakburn GL. Current therapy in nutrition. Toronto, Philadelphia: BC Decker Inc 1988; pp. $269-78$.

[63] Heyland DK, Konopad E, Alberda C, Keefe L, Cooper C, Cantwell B. How well do critically ill patients tolerate early, intragastric enteral feeding? Results of a prospective, multicenter trial. Nutr Clin Pract 1999; 14: 23-8.

[http://dx.doi.org/10.1177/088453369901400105]

[64] Rello J, Quintana E, Ausina V, et al. Incidence, etiology, and outcome of nosocomial pneumonia in mechanically ventilated patients. Chest 1991; 100(2): 439-44. [http://dx.doi.org/10.1378/chest.100.2.439] [PMID: 1864118]

[65] Volkert D, Berner YN, Berry E, et al. DGEM (German Society for Nutritional Medicine); ESPEN (European Society for Parenteral and Enteral Nutrition). ESPEN Guidelines on Enteral Nutrition: Geriatrics. Clin Nutr 2006; 25(2): 330-60. [http://dx.doi.org/10.1016/j.clnu.2006.01.012] [PMID: 16735082]

[66] Milne AC, Potter J, Avenell A. Protein and energy supplementation in elderly people at risk from malnutrition. Cochrane Database Syst Rev 2005; (1):

[http://dx.doi.org/10.1002/14651858.CD003288.pub2]

[67] Simpson F, Doig GS. Parenteral vs. enteral nutrition in the critically ill patient: a meta-analysis of trials using the intention to treat principle. Intensive Care Med 2005; 31(1): 12-23. [http://dx.doi.org/10.1007/s00134-004-2511-2] [PMID: 15592814] 
[68] Marik PE, Zaloga GP. Early enteral nutrition in acutely ill patients: a systematic review. Crit Care Med 2001; 29(12): 2264-70. [Erratum in: Crit Care Med 2002; 30: 725]. [http://dx.doi.org/10.1097/00003246-200112000-00005] [PMID: 11801821]

[69] Leite HP, Fantozzi G. Metabolic assessment and enteral tube feeding usage in children with acute neurological diseases. Sao Paulo Med J 1998; 116(6): 1858-65. [http://dx.doi.org/10.1590/S1516-31801998000600006] [PMID: 10349194]

[70] O'Keefe SJ. A guide to enteral access procedures and enteral nutrition. Nat Rev Gastroenterol Hepatol 2009; 6(4): 207-15. [http://dx.doi.org/10.1038/nrgastro.2009.20] [PMID: 19347012]

[71] DeLegge MH, McClave SA, DiSario JA, et al. Ethical and medicolegal aspects of PEG-tube placement and provision of artificial nutritional therapy. Gastrointest Endosc 2005; 62(6): 952-9. [http://dx.doi.org/10.1016/j.gie.2005.08.024] [PMID: 16301043]

[72] Fay DE, Poplausky M, Gruber M, Lance P. Long-term enteral feeding: a retrospective comparison of delivery via percutaneous endoscopic gastrostomy and nasoenteric tubes. Am J Gastroenterol 1991; 86(11): 1604-9. [PMID: 1951237]

[73] Guo S, DiPietro LA. Factors affecting wound healing. J Dent Res 2010; 89: 219-29.

[74] Eleazer GP, Bird L, Egbert J, Ryan C, Wei M, Guest K. Appropriate protocol for zinc therapy in long term care facilities. J Nutr Elder 1995; 14(4): 31-8.

[http://dx.doi.org/10.1300/J052v14n04_03] [PMID: 8708978]

[75] ter Riet G, Kessels AG, Knipschild PG. Randomized clinical trial of ascorbic acid in the treatment of pressure ulcers. J Clin Epidemiol 1995; 48(12): 1453-660

[http://dx.doi.org/10.1016/0895-4356(95)00053-4] [PMID: 8543959]

(C) Dionyssiotis et al.; Licensee Bentham Open.

This is an open access article licensed under the terms of the Creative Commons Attribution-Non-Commercial 4.0 International Public License (CC BY-NC 4.0) (https://creativecommons.org/licenses/by-nc/4.0/legalcode), which permits unrestricted, non-commercial use, distribution and reproduction in any medium, provided the work is properly cited. 